\title{
Evidence of herpesvirus (OsHV-1) resistance in juvenile Crassostrea gigas selected for high resistance to the summer mortality phenomenon
}

\author{
Lionel Dégremont ${ }^{*}$, a \\ a IFREMER, Laboratoire de Génétique et Pathologie, 17390 La Tremblade, France \\ * Corresponding author : Lionel Dégremont, Tel.: + 335467626 30; fax: + 335467626 11, email address : \\ lionel.degremont@ifremer.fr
}

\begin{abstract}
:
During the MOREST project (2001-2006), oyster summer mortality was extensively investigated in Crassostrea gigas in France. However, significant increases in magnitude and geographic distribution of summer mortality episodes have been reported since 2008. This paper investigates the response to selection for survival, which was successfully performed between 2001 and 2003, in this new context. It also examines the relationship between the mortality and the three pathogens Vibrio aestuarianus, V. splendidus and the Ostreid herpesvirus 1 (OsHV-1). Three batches of juvenile (6-month-old) Crassostrea gigas were produced in February 2009 and tested in the field in the Marennes-Oléron Bay during summer (August and September) 2009: one control batch, one batch descended from one family selected to be resistant $(R)$ to the summer mortality phenomenon and one descended from one family selected to be susceptible (S). For each batch, mortality was monitored and oysters were diagnosed for the presence and intensity of the three pathogens. A mortality episode started 11 days post deployment and had finished by day 17 . A significant difference in mortality was found among the batches, with 5,53 and $94 \%$ for the R, control and S batches, respectively. This finding indicates that the selection previously made for resistance to summer mortality still confers an advantage for the survival of juvenile $C$. gigas to descendant batches in the context of the recent massive oyster mortality that has occurred in France since 2008. Disease diagnoses revealed $V$. splendidus at all sampling dates but never $V$. aestuarianus, showing that only the first of these bacteria could have been involved in this mortality event. However correlations between the mortality and the presence or the bacterial load of $V$. splendidus were weak, negative and not significant. In contrast, high and significant correlations were found between the mortality and the prevalence of OsHV-1, as well as between the mortality and OsHV-1 viral load. This study clearly revealed the suddenness of the infection in juvenile C. gigas in field conditions, as no OsHV-1 was detected in seed at deployment, while all juvenile oysters tested 7 days post-deployment were infected and the peak of the viral load was observed 11 days post-deployment. Finally, this study is the first report of herpesvirus resistance in the R oysters. Even if all R oysters had been infected by the OsHV-1, they were able, first, to limit the amount of the viral load in their tissues, and, second, either to eliminate the virus from their tissue or to decrease the quantity of viral DNA to a level below the threshold of the real-time PCR technique, as OsHV-1 prevalence decreased from $100 \%$ to $33 \%$ for the R oysters screened at 7 and 17 days post-deployment, respectively.
\end{abstract}

Keywords: Summer mortality; Crassostrea gigas; Disease resistance; Ostreid herpesvirus; Vibrio sp; Oyster 


\section{Introduction}

Summer mortality in Crassostrea gigas (Thunberg) is known to be the result of complex interactions between the oysters, pathogens and the environment; therefore, it cannot be explained by a single factor (Glude, 1975; Koganezawa, 1975). The phenomenon was extensively studied in juvenile and adult oysters $C$. gigas in France during the MOREST program from 2001 to 2006 (Samain and McCombie, 2008). A multi-disciplinary approach was taken in order to improve understanding of the causes of summer mortality in C. gigas and to find ways of reducing its impact on oyster production. One of the major findings was the high genetic variance for survival found in oysters younger than one year (Dégremont et al., 2007). A positive response to selection was also observed following divergent selection for increased and decreased survival during a summer mortality outbreak in juvenile $C$. gigas (Dégremont et al., 2010a), indicating that selective breeding programs could improve oyster survival very efficiently. A selection program of this sort was not, however, the top priority for the oyster industry in France, as the level of mortality in juvenile $C$. gigas did not significantly affect production (stable at around 110000 tons per year; FAO, 2010). Indeed, oyster farmers considered 20 - 40\% mortality in unselected juvenile oysters as normal in sites where mortality commonly occurs in France. This rate was observed during the MOREST program, except in 2003 , when mortality almost doubled, potentially due to an exceptional summer heat wave that year (Dégremont et al., 2010a, 2010b). Unfortunately, major oyster mortality episodes have occurred since 2008 in France (Pernet et al., 2010; Segarra et al., 2010) as well as Ireland (Malham et al., 2009). These mostly affected juvenile C. gigas younger than one year old and mortality rates reached 70 to $100 \%$ in most growing areas in France. As it usually takes oysters three years to reach market size, French oyster production will dramatically decrease from 2011 due to the lack of juveniles for three consecutive years. Given this situation, a new generation of oysters was produced from the families selected during the MOREST project for resistance or susceptibility to the summer mortality. These descendant families, along with a control bred from wild-collected oysters, were produced and tested in 2009 in order to determine whether the selection performed in 2001 would still have an effect in the context of the new wave of widespread mortality. Additionally, because the pathogens Ostreid herpesvirus 1 (OsHV-1), Vibrio splendidus and Vibrio aestuarianus have been found to be associated with some cases of mortality in juvenile C. gigas in France (Lacoste et al., 2001; Le Roux et al., 2002; Nicolas et al., 2008), pathology investigations were performed to provide a better understanding of the role of these three pathogens in the recent massive mortality events observed in France.

\section{Materials and methods}

\subsection{Oyster batches}

During the MOREST program, a first generation composed of 44 bi-parental oyster families was produced from a wild population and then field-tested in 2001. From their survival to 6 months of age, 6 families showing high survival and 6 families showing low survival were selected as 'resistant' and 'susceptible' to the summer mortality phenomenon; these groups are hereafter referred to as R and S, respectively. Each selected family was then reproduced for four generations between 2002 and 2007, without any further round of selection, by always using genitor oysters that had been protected from the mortality occurring in the field. Indeed, as heritability for survival is moderate to high in juvenile $C$. gigas, had $\mathrm{S}$ oysters been exposed to mortality risks, then retaining survivors for breeding would confer superior resistance to their offspring. This would increase survival of the $S$ families and, therefore, decrease the difference in susceptibility to mortality risks between the 
$\mathrm{R}$ and $\mathrm{S}$ families, throughout the successive generations (Dégremont et al., 2007, 2010a, $2010 \mathrm{~b})$. For the present study, one $\mathrm{R}$ family and one $\mathrm{S}$ family of the fifth generation were randomly chosen to produce the selected batches. Unselected oysters were sampled from a wild population at Agnas,in the Marennes-Oléron Bay, to produce a control batch. The three batches were spawned on 23 February 2009 at the IFREMER hatchery in La Tremblade. Further details on crosses, larval rearing, settlement, nursing and the selection criteria are given in Dégremont et al. (2005, 2007, 2010a). Briefly, each cross used, on average, 7 males and 21 females. Larvae were obtained the following day and were raised until they could be caught on a $220 \mu \mathrm{m}$ screen. The larvae were then settled and, when spat reached a size of $2 \mathrm{~mm}$, they were transferred into the IFREMER nursery located in Bouin on April 22, where they remained until field deployment.

\subsection{Field study}

On 28 August 2009, the oysters were deployed at Agnas in Marennes-Oléron Bay, at the same location where the wild oysters used to produce the control batch had been sampled. For each batch, two plastic-mesh oyster bags, each containing 300 oysters, were fixed in random positions to one rack. A buoy was attached to this rack so that it could be lifted on board a boat during the neap tide, thus enabling continuous access to the oysters for mortality counts and disease sampling. Dead and living oysters were counted on August 31 and September 4, 8, 11, 14, 21 and 28. Dying oysters were always left inside the bags in order to avoid an unintentional clean up of the immediate environment by removing oysters susceptible to die due to a pathogen that could be then spread in the vicinity. Twenty-four oysters per batch were sampled for disease investigation on August 27 at the nursery in order to know the initial disease status before deployment. Samples of 12 oysters per batch were then sampled on August 31 and September 4, 8, 14 and 21.

\subsection{Disease testing}

Oysters were individually tested for OsHV-1, Vibrio splendidus and Vibrio aestuarianus. For each oyster, the shell and digestive gland were removed and the remaining wet tissue was weighed and then crushed in four times its volume of artificial sea water. The resulting homogenate was centrifuged at $1000 \mathrm{~g}$ for $1 \mathrm{~min}$ and supernatant was immediately used for disease screening.

OsHV-1 detection and quantification. Detection and quantification of OsHV-1 was performed using real-time PCR technique developed by Pépin et al. (2008), using the protocol described in Sauvage et al. (2009). Briefly, DNA was extracted from $100 \mu \mathrm{l}$ of supernatant, using the QiagenQiamp ${ }^{\circledR}$ tissue mini kit, and final DNA elution was performed with $100 \mu \mathrm{l}$ of double-distilled water. Then, $5 \mu \mathrm{l}$ of 200 -fold diluted DNA diluted was used for real-time PCR (Stratagene) in a final reaction volume of $25 \mu \mathrm{l}$, with the following cycles: initial denaturation 10 min at $95{ }^{\circ} \mathrm{C}$, followed by 40 cycles of $95^{\circ} \mathrm{C}$ for $30 \mathrm{~s}, 60^{\circ} \mathrm{C}$ for $1 \mathrm{~min}$ and $72{ }^{\circ} \mathrm{C}$ for $45 \mathrm{~s}$. In these quantitative PCR tests, the primer pairs used to detect viral DNA were those described in Webb et al. (2007) for targeting OsHV-1 DNA polymerase.

Vibrio splendidus and Vibrio aestuarianus detection and quantification. For detection and quantification of the two vibrio species, $100 \mu \mathrm{l}$ of supernatant was diluted 100 -fold and 10 000-fold and each dilution was spread onto Marine agar (Difco) in Petri dishes, which were incubated for 76 hours at $20^{\circ} \mathrm{C}$. Colonies were enumerated and one of the bacterial colonies found in abundance was picked up and tested by duplex PCR for the detection of 
Vibrio splendidus and Vibrio aestuarianus following the protocol described in Saulnier et al. (2007, 2009).

\subsection{Statistical analyses}

As no Vibrio aestuarianus was found in any oyster in this study, data on this pathogen was not included in any of the statistical analyses performed. All statistical analyses were done using the SAS ${ }^{\circledR}$ software version 9. Mortality, and prevalence of OsHV-1 and Vibrio splendidus were analysed per sampling date using the GENMOD procedure with a logit transformation and a binomial distribution throughout the following model:

Logit $(Y i)=\log (Y i /(1-Y i))=\mu+$ batch $i$,

where $\mathrm{Y} i$ is the probability of an unfavourable response (mortality = dead; OsHV-1 = present; Vibrio splendidus = present) for the ith batch ( $\mathrm{R}, \mathrm{S}$ and control), $\mu$ is the intercept, batch $i$ is the effect of the ith batch. Multiple comparison tests were conducted using the least squares means statement and the pdiff option (Littell et al., 2002).

The same model was used to analyse the viral load of OsHV-1 and the bacterial load of $V$. splendidus, which were both log $(Y+1)$ transformed, through an ANOVA using the GLM procedure, $Y$ being the viral load (DNA copy number per mg of fresh tissue) or the bacterial load (number of colonies per $g$ of fresh tissue). Finally, Pearson correlations were calculated between mortality and the prevalence and load of OsHV-1 and $V$. splendidus using the transformed data and the CORR procedure. For the mortality, difference of mortality between two sampling dates was used instead of the cumulative mortality and all correlations between mortality and disease data were calculated at $T+1$ for the former and $T$ for the latter, respectively, as a causality link should exist between a disease and the related mortality.

\section{Results}

\subsection{Mortality}

Mortality started clearly at 11 days after deployment in the $\mathrm{S}$ batch and to a lesser extent in the control batch (Fig. 1). It then increased sharply for nearly a week in both of these two batches, but 17 days after deployment this mortality episode had finished. At the end of the experiment, mortality was 5, 53 and 94\% for the R batch, the control and the S batch, respectively. Significant differences in mortality among these batches were found from day 11 post-deployment until the end of the experiment $\left(107<\chi^{2}<1150 ; P<0.0001\right)$, with the highest mortality occurring in the $\mathrm{S}$ batch, the lowest in the $\mathrm{R}$ batch and an intermediate value in the control.

\subsection{Herpesvirus OsHV-1 detection and quantification}

At deployment, herpesvirus OsHV-1 was not detected in any of the 72 oysters tested (Fig. 2a). Three days post-deployment, similar results were found for the $\mathrm{R}$ and control batches, while the virus was detected in one individual of the sample from the $S$ batch. One week post-deployment, prevalence of the virus reached $100 \%$ for the three batches, and remained at this level for the $S$ and control batches until 17 days post-deployment. For the R batch, prevalence decreased from $92 \%$ at 10 days post-deployment to $33 \%$ at 17 days postdeployment. Finally, at 24 days post-deployment, OsHV-1 prevalence in the R batch had decreased still further, to $17 \%$, while it had just started to decrease slightly for the $\mathrm{S}$ and control batches. Significant differences of OsHV-1 prevalence among batches were found at 17 and 24 days post-deployment, with the lowest prevalence for the $\mathrm{R}$ batch and higher and 
similar prevalence in the $S$ and control batches $\left(17.4<\chi^{2}<18.6 ; P<0.0001\right)$. The viral load, increased sharply between 3 and 11 days post-deployment, to reach peaks at 4.6, 7.0 and 7.6 on the logarithmic scale for the R, control and $S$ batches, respectively (Fig. 2b), which correspond before transformation to $4.10^{+4}, 1.10^{+7}$ and $4.10^{+7}$ DNA copies per mg of fresh tissue. The viral load then decreased for all three batches, especially in the $\mathrm{R}$ batch. The $\mathrm{R}$ batch, consequently, had a significantly lower viral load than the two other batches from 7 to 24 days post-deployment $(13.5<\mathrm{F}<23.3 ; P<0.0001)$.

\subsection{Vibrio splendidus and Vibrio aestuarianus detection and quantification}

No Vibrio aestuarianus were detected in any batch at any time, while Vibrio splendidus was detected in all batches at all sampling dates. Prevalence of $V$. splendidus ranged from 17 to $75 \%$ (Fig. 3) and mean bacterial load was always below 3 on the logarithmic scale (Fig.3). No significant difference among batches for the prevalence of $V$. splendidus $\left(0.91<\chi^{2}<\right.$ 5.58; $P>0.05)$ or the bacterial load $(0.30<\mathrm{F}<1.89 ; P>0.05)$, was found at any sampling date.

\subsection{Correlation}

High and significant correlations were found between mortality and the prevalence of OsHV1 ( $r=0.67$ and $P<0.01$ ), between mortality and OsHV-1 viral load $(r=0.81 ; P<0.0001)$ and between prevalence and OsHV-1 viral load $(r=0.95 ; P<0.0001)$. Neither mortality nor OsHV-1 parameters were found to correlate significantly with $V$. splendidus parameters, and correlations among those variables remained weak $(-0.26<r<0.16)($ Table 1$)$.

\section{Discussion}

Mortality occurred in all three experimental batches at the beginning of September 2009. In the same area (Marennes-Oléron Bay), mortality peaks had already been reported in cultivated juvenile $C$. gigas in May 2009. Consequently the risk period favouring summer mortality, as defined by Ropert et al. (2007), spanned a long period, with interactions between the environment, pathogens and juvenile $C$. gigas still favouring mortality in September.

Importantly, a large difference in mortality was observed between the $\mathrm{R}$ and $\mathrm{S}$ batches at the end of the study. This is in agreement with results found by Dégremont et al. (2010a), and confirms the positive response to selection to decrease or increase the mortality compared to the control batch in the context of the new massive mortality occurring in France. It is important to remember that the selection was made according to the survival performances recorded in oyster families produced and tested in 2001 . The results, therefore, indicate that the selection criterion was still effective in the new context. The results indicate that either the mortality observed in 2001 had similar causes to that recorded in 2009 or the selection performed in 2001 to produce the R oysters had resulted in an overall higher resistance to stresses in general.

Kinetics of the mortality revealed that high mortality occurred within the first two weeks postdeployment. This result contrasts with the findings of Dégremont et al. (2005, 2010a), testing previous generations of the same families, where any abnormal mortality was observed within the first two weeks post-deployment. This difference could be explained by a much higher incidence of the herpesvirus and a consequent higher probability of infection in the period since 2008, compared with the 2001-2003 period. Nevertheless, mortality kinetics confirmed that the mortality in juvenile $C$. gigas in the present study is a short term event and, therefore, resembles the mortality described first in laboratory experiments conducted 
since 2001 using the $\mathrm{R}$ and $\mathrm{S}$ batches and controls (Dégremont, 2003; Dégremont et al., 2010c), and in F2 families dedicated to investigations on QTL for resistance to summer mortality and OsHV-1 load in juvenile C. gigas in 2006 (Sauvage et al., 2009).

While it seems obvious that Vibrio aestuarianus was not involved in the mortality observed, no clear relationship with Vibrio splendidus was indicated either. Even though $V$. splendidus was found in each batch on all the sampling dates, no significant correlation was found between mortality and prevalence of $V$. splendidus: the relationship was negative, weak and not significant (Table 1).

In contrast, this study provides new and major findings concerning the significant correlations detected between the mortality and OsHV-1 parameters in field conditions. Interestingly, the kinetics of the detection and quantification of the OsHV-1 in the oysters tested in field conditions showed that detection rose from $0 \%$ to $100 \%$ during the first week postdeployment for the three tested batches (Fig. 2a). Two main hypotheses can be proposed to explain this contamination. The first hypothesis is that oysters were contaminated in the field via the wild or cultivated oysters there, or by other organisms growing around the tested batches. Indeed, heavy mortality had already been reported in this site from May to August in juvenile C. gigas, for which OsHV-1 was detected in moribund oysters. Viral particles could have been transported through seawater, as found by Vigneron et al. (2004) and more recently in Schikorski et al. (2011), and these particles could then have contaminated the juvenile $C$. gigas. The second hypothesis is that some of the oysters deployed were already infected by OsHV-1 before field deployment. The non detection of such animals could be explained by the detection threshold of the real-time PCR assay (Pépin et al., 2008) combined with the low sample size (only 72 animals were screened), which increases the uncertainty about the true prevalence in the population (Jovani and Tella, 2006). Despite this uncertainty about the initial prevalence of OsHV-1 before deployment, the data clearly showed that contamination and/or proliferation led to an extremely rapid increase in OsHV-1 prevalence in all C. gigas juveniles in the field, as prevalence went from 0-8 \% to $100 \%$ between the $3^{\text {rd }}$ and the $7^{\text {th }}$ day post-deployment (Fig. 2a). OsHV-1 viral load increased sharply between the $3^{\text {rd }}$ and the $11^{\text {th }}$ days post-deployment for the $\mathrm{S}$ and control batches, but to a lesser extent for the $\mathrm{R}$ batch (Fig. $2 \mathrm{~b}$ ). The mortality peak immediately followed the viral load peak, clearly implicating OsHV-1 in this case of mortality. The most interesting result concerned the R batch: even though OsHV-1 was detected in all R oysters screened at day 7 post-deployment (Fig. 2a), they were able to contain the proliferation of OsHV-1 in comparison with the other two batches (Fig. 2b). While the $S$ and control batches suffered tremendous mortalities between 11 and 17 days post-deployment, the R oysters did not, as overall mortality for this batch had only reached $5 \%$ at the end of the experiment. Meanwhile, prevalence and viral load remained high for the $S$ and control batches while 83 $\%$ of the $\mathrm{R}$ oysters were able either to decrease the quantity of viral DNA below the threshold of the real-time PCR technique or even better, to eliminate the virus from their tissues.. These results clearly confirm a genetic basis for resistance to OsHV-1 infection in the Pacific oyster, as suggested by Sauvage et al. (2009). Thus, R batch oysters tested under the conditions of this study, produced from crosses made in February and grown in a nursery until deployment to the field in August, were resistant to the herpesvirus OsHV-1. This is the first report clearly showing disease resistance to OsHV-1 in R juvenile C. gigas compared to the $S$ and control batches, and confirms the first results collected in 2002 and 2003 when a massive mortality outbreak, associated with the detection of the OsHV-1, occurred in both hatchery and nursery facilities for the $S$ batches, while $R$ batches did not suffer such abnormal mortality (Dégremont, 2003; Dégremont et al., 2010c).

Finally, these results showed that there is a high probability of observing mortality due to the OsHV-1 within the 2 weeks following deployment for all batches of unselected juvenile $C$. gigas according to two conditions: the batch has to be naïve (i.e. juvenile oysters had never been in contact with OsHV-1) and interactions between oysters, pathogens and the environment still favour mortality, which corresponds to period between May and September. 


\section{Acknowledgements}

We want to thank the hatchery, nursery and genetics teams at the Laboratory of Genetics and Pathology, IFREMER La Tremblade and IFREMER Bouin, for their assistance with the oyster production, as well as Jean Luc Seugnet and Philippe Geairon for their help with field operations. We also thank Dr Tristan Renault, Dr Jean François Pépin, Dr Denis Saulnier and Cyril François for their advice on pathology.

\section{References}

Dégremont, L., 2003. Etude des bases génétiques des mortalités estivales et relation avec la croissance chez les juvéniles de Crassostrea gigas. Thèse de Doctorat de l'Université de Caen, France. (333p).

Dégremont, L., Bédier, E., Soletchnik, P., Ropert, M., Huvet, A., Moal, J., Samain, J.F., Boudry, P., 2005. Relative importance of family, site, and field placement timing on survival, growth, and yield of hatchery-produced Pacific oyster spat (Crassostrea gigas). Aquaculture 249, 213-229.

Dégremont, L., Ernande, B., Bédier, E., Boudry, P., 2007. Summer mortality of hatcheryproduced Pacific oyster spat (Crassostrea gigas). I. Estimation of genetic parameters for survival and growth. Aquaculture 262, 41-53.

Dégremont, L., Bédier, E., Boudry, P., 2010a. Summer mortality of hatchery-produced Pacific oyster spat (Crassostrea gigas). II. Response to selection for survival and its influence on growth and yield. Aquaculture 299, 21-29.

Dégremont, L., Boudry, P., Ropert, M., Samain, J.-F., Bédier, E., Soletchnik, P., 2010b. Effects of age and environment on survival of summer mortality by two selected groups of the Pacific oyster Crassostrea gigas. Aquaculture 299, 44-50.

Dégremont, L., Soletchnick, P., Boudry, P., 2010c. Summer mortality of selected juvenile Pacific oyster Crassostrea gigas under laboratory conditions and comparison with field performance. J. Shellfish Res. 29, 847-856.

FAO, 2010. Aquaculture production: Quantities and values 1950-2008. Fishstat Plus. Published electronically on the internet, available directly from http://www.fao.org/fi/statist/fisoft/FISHPLUS.asp\#Download

Glude, J.B., 1975. A summary report of Pacific coast oyster mortality investigations 19651972. Proceedings of the Third U.S.-Japan, Meeting on Aquaculture, Tokyo, Japan. October 15-16, 1974, pp. 1-28.

Jovani, R., Tella, J.L., 2006. Parasite prevalence and sample size: misconceptions and solutions. Trends Parasitol. 22, 214-218.

Koganezawa, A., 1975. Present status of studies on the mass mortality of cultured oysters in Japan and its prevention. Proceedings of the Third U.S.-Japan Meeting on Aquaculture, October 15-16, 1974, Tokyo, Japan, pp. 29-34.

Lacoste, A., Jalabert, F., Malham, S., Cueff, A., Gelebart, F., Cordevant, C., Lange, M., Poulet, S.A., 2001. A Vibrio splendidus strain is associated with summer mortality of juvenile oysters Crassostrea gigas in the Bay of Morlaix (North Brittany, France). Dis. Aquat. Organ. 46, 139-145.

Le Roux, F., Gay, M., Lambert, C., Waechter, M., Poubalanne, S., Chollet, B., Nicolas, J.L., Berthe, F., 2002. Comparative analysis of Vibrio splendidus-related strains isolated during Crassostrea gigas mortality events. Aquat. Living Resour. 15, 251-258.

Littell, R.C., Stroup, W.W., Freund, R.J., 2002. SAS® for Linear Models, Fourth Edition. Cary, NC.

Malham, S.K., Cotter, E., O'Keeffe, S., Lynch, S., Culloty, S.C., King, J.W., Latchford, J.W., Beaumont, A.R., 2009. Summer mortality of the Pacific oyster, Crassostrea gigas, in the Irish 
Sea: The influence of temperature and nutrients on health and survival. Aquaculture 287, 128-138.

Nicolas, J.L., Renault, T., Gagnaire, B., Garcia, C., Garnier, M., Gay, M., Labreuche, Y., Le Roux, F., Miossec, L., Pépin, J.F., Saulnier, D., 2008. Oyster summer mortaly risks associated with pathogens, in: Samain, J.F., McCombie, H. (Eds.), Summer Mortality of Pacific Oyster Crassostrea gigas. The Morest Project. Quae Editions, Versailles, pp. 243287.

Pépin, J.F., Riou, A., Renault, T., 2008. Rapid and sensitive detection of ostreid herpesvirus 1 in oyster samples by real-time PCR. J. Virol. Methods 149, 269-276.

Pernet, F., Barret, J., Marty, C., Moal, J., Le Gall, P., Boudry, P., 2010. Environmental anomalies, energetic reserves and fatty acid modifications in oysters coincide with an exceptional mortality event. Mar. Ecol. Prog. Ser. 401, 129-146.

Ropert, M., Mazurié, J., Bédier, E., Le Coz, F., Soletchnick, P., 2007. Evaluation of summer mortality risk factors in shellfish farming ecosystems, in: Samain, J.F., McCombie, H. (Eds.), Summer Mortality of Pacific Oyster Crassostrea gigas. The Morest Project. Quae Editions, Versailles, pp. 1-61.

Samain, J.F., McCombie, H., 2008. Summer mortality of Pacific oysters Crassostrea gigas. The MOREST Project. Quae Editions, Versailles, 379p.

Saulnier, D., De Decker, S., Haffner, P., 2009. Real-time PCR assay for rapid detection and quantification of Vibrio aestuarianus in oyster and seawater: A useful tool for epidemiologic studies. J. Microbiol. Meth. 77, 191-197.

Saulnier, D., De Decker, S., Haffner, P., Duperthuy, M., Le Roux, F., 2007. Development of diagnostic tools for the detection of Vibrio species and pathogenic strains associated with mortalities of cultured pacific cupped oyster Crassostrea gigas in France. Vibrio 2007 meeting, Pasteur Institute, Paris (France). pp. 191.

Sauvage, C., Pépin, J.F., Lapègue, S., Boudry, P., Renault, T., 2009. Ostreid herpes virus 1 infection in families of the Pacific oyster, Crassostrea gigas, during a summer mortality outbreak: Differences in viral DNA detection and quantification using real-time PCR. Virus Res. 142, 181-187.

Schikorski, D., Faury, N., Pepin, J.F., Saulnier, D., Tourbiez, D., Renault, T., 2011. Experimental Ostreid herpesvirus 1 (OsHV-1) infection of the Pacific oyster Crassostrea gigas: Kinetics of virus DNA detection by q-PCR in seawater and in oyster samples. Virus Res. 155, 28-34..

Segarra, A., Pépin, J.F., Arzul, I., Morga, B., Faury, N., Renault, T., 2010. Detection and description of a particular Ostreid herpesvirus 1 genotype associated with massive mortality outbreaks of Pacific oysters, Crassostrea gigas, in France in 2008. Virus Res. 153, 92-99.

Vigneron, V., Solliec, G., H, M., Renault, R., 2004. Detection of Ostreid Herpesvirus 1 (OsHV-1) DNA in seawater by PCR: influence of water parameters in bioassays. Dis. Aquat. Organ. 62, 35-44.

Webb, S.C., Fidler, A., Renault, T., 2007. Primers for PCR-based detection of ostreid herpes virus-1 (OsHV-1): Application in a survey of New Zealand molluscs. Aquaculture 272, 126139. 


\section{Figures}

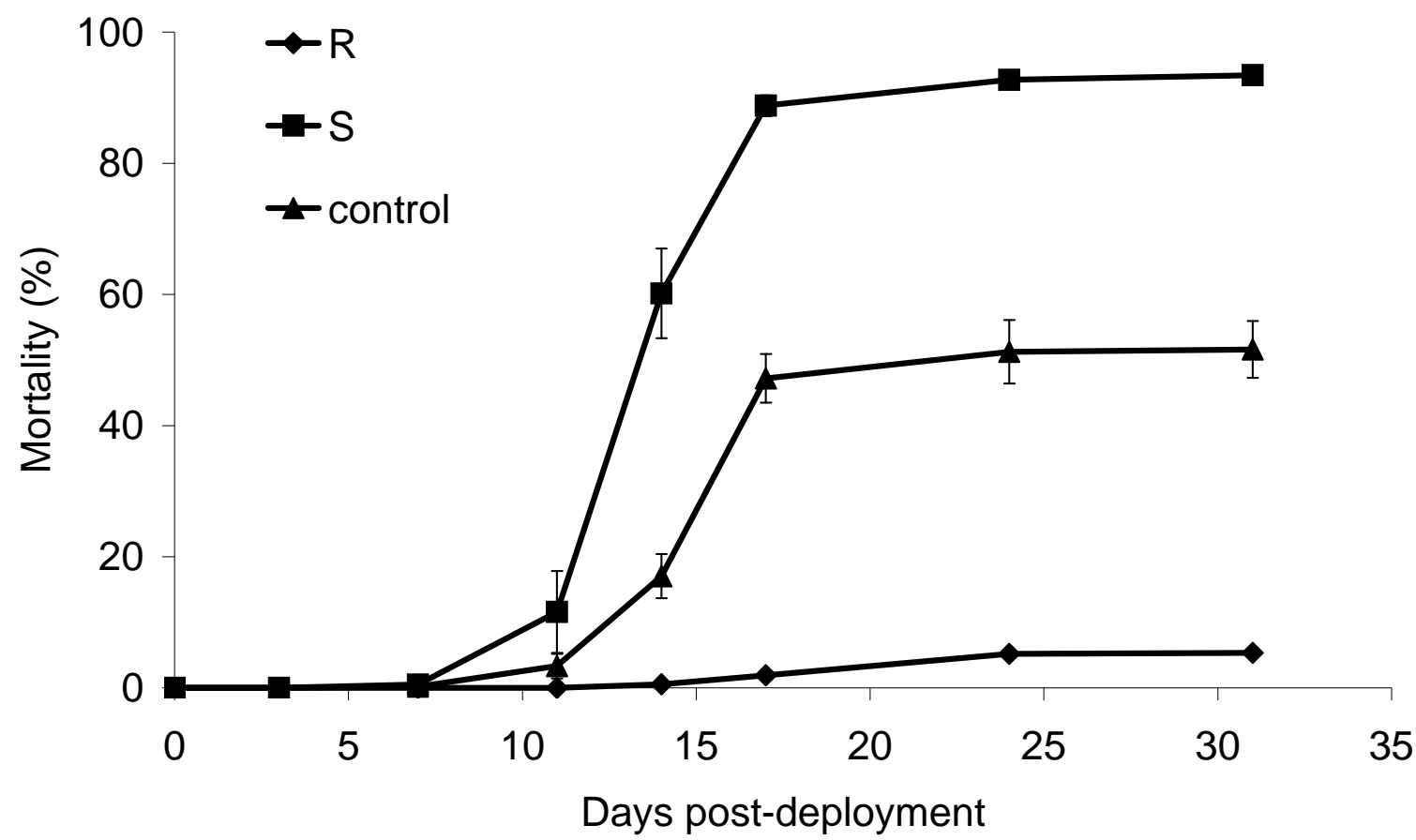

Fig. 1. Cumulative mortality for the $R, S$ and control batches (bars represent the standard error among the two bags). $\mathrm{R}$ and $\mathrm{S}$ are selected oyster groups, 'resistant' and 'susceptible' to summer mortality, respectively. 
(a)

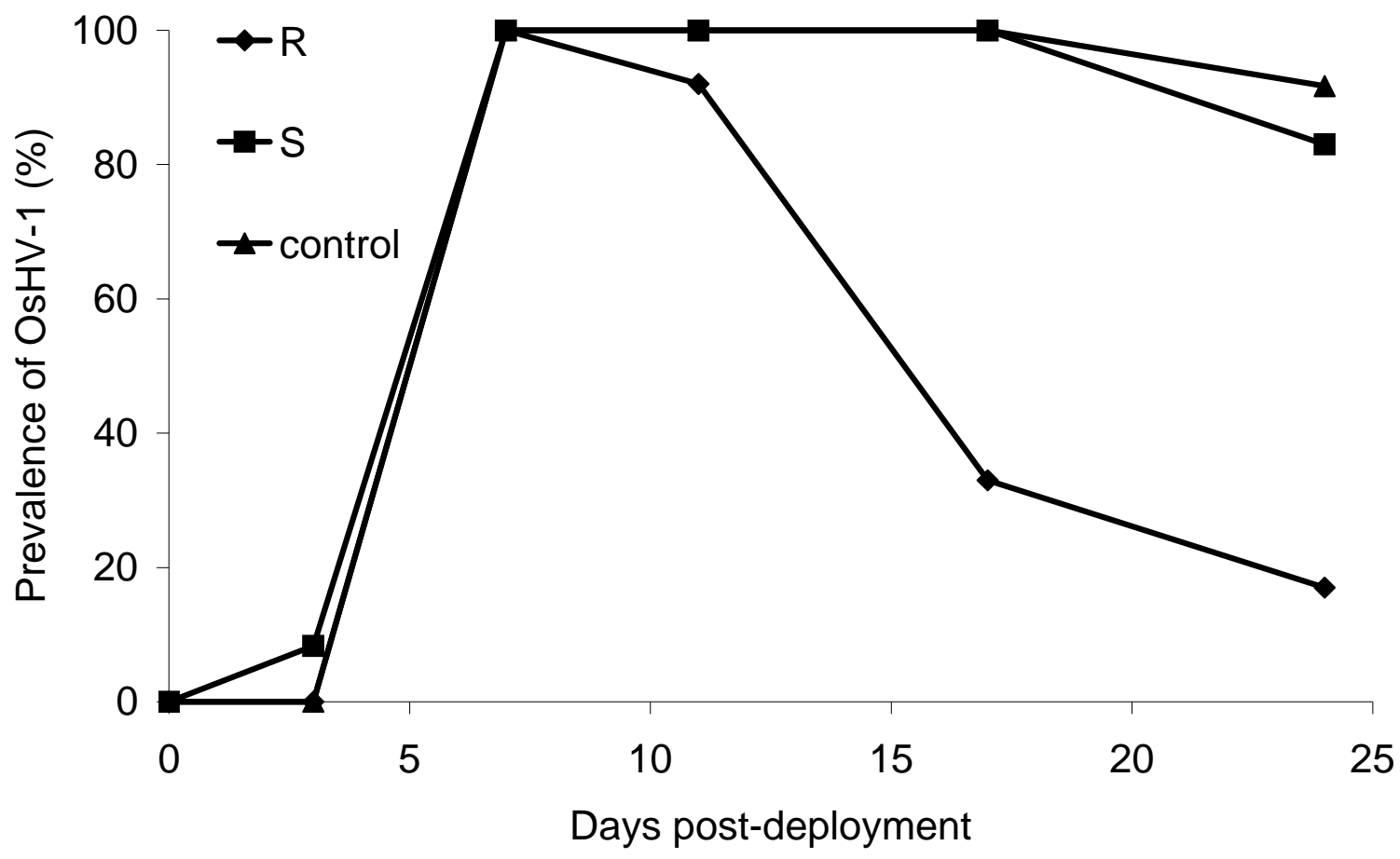

(b)

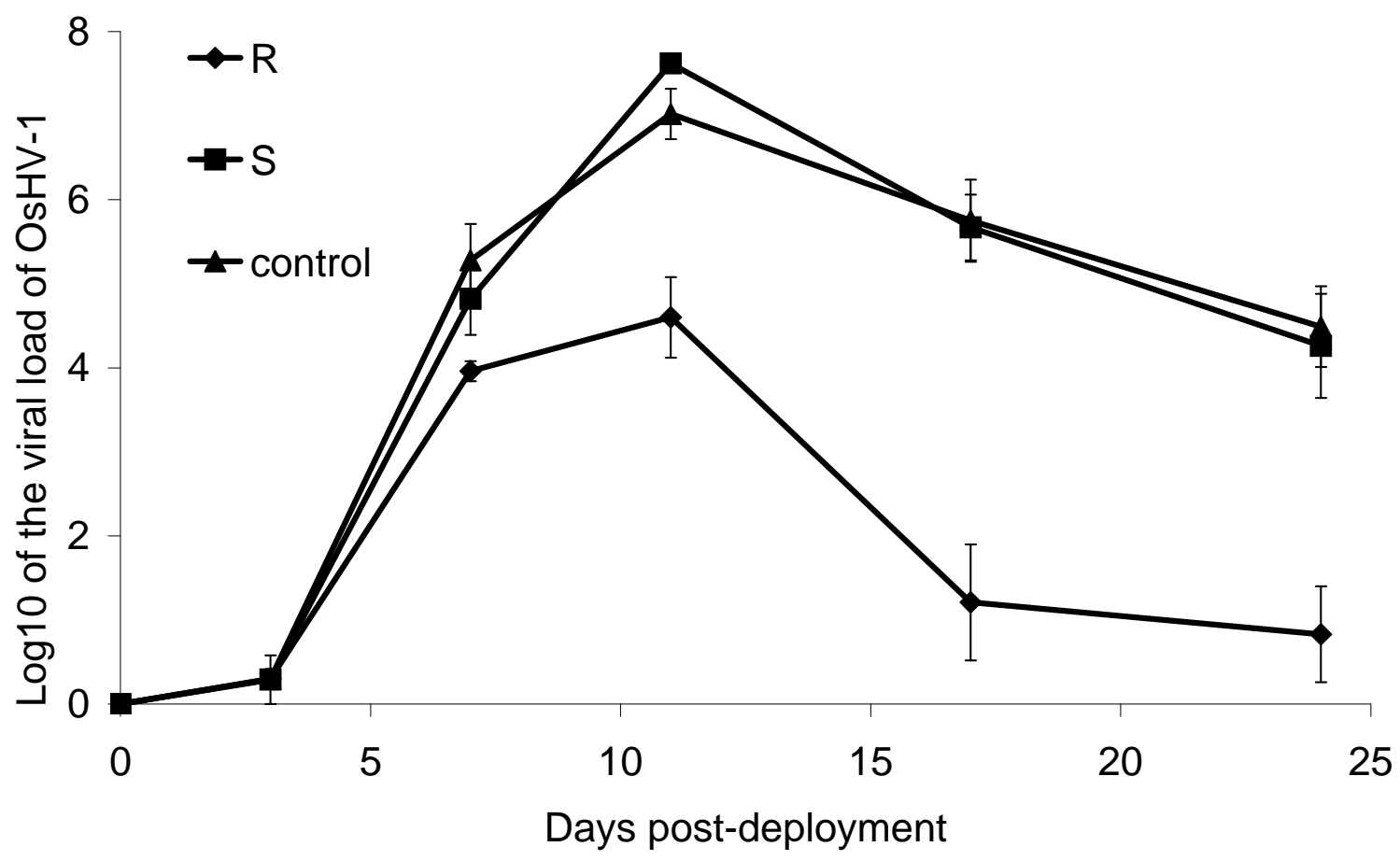

Fig. 2. Kinetics of the prevalence and the viral load (number of DNA copies per mg of fresh tissue) of OsHV-1 for the R, S and control batches (bars represent the standard error). $\mathrm{R}$ and $\mathrm{S}$ are selected oyster groups, 'resistant' and 'susceptible' to summer mortality, respectively. 
(a)

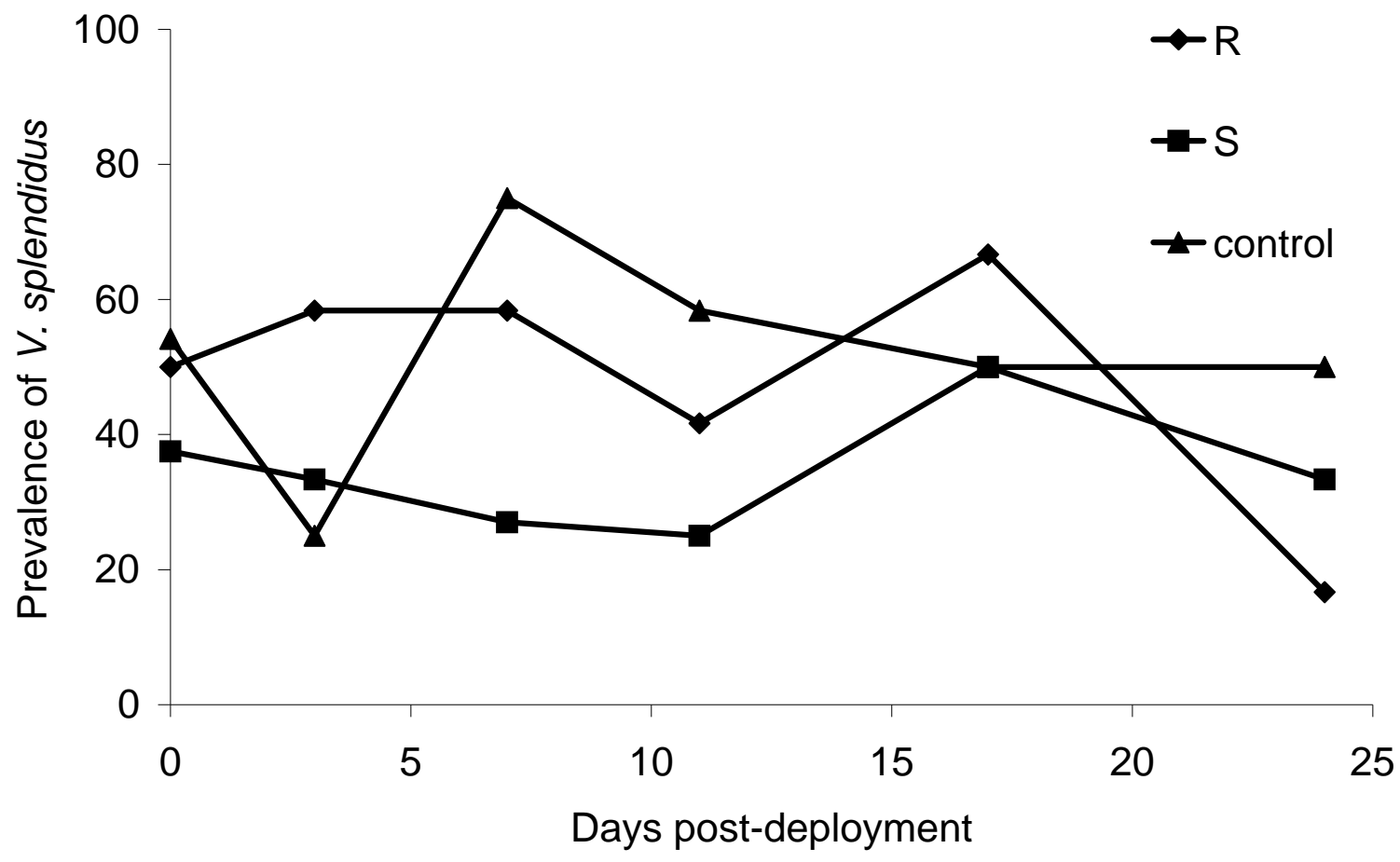

(b)

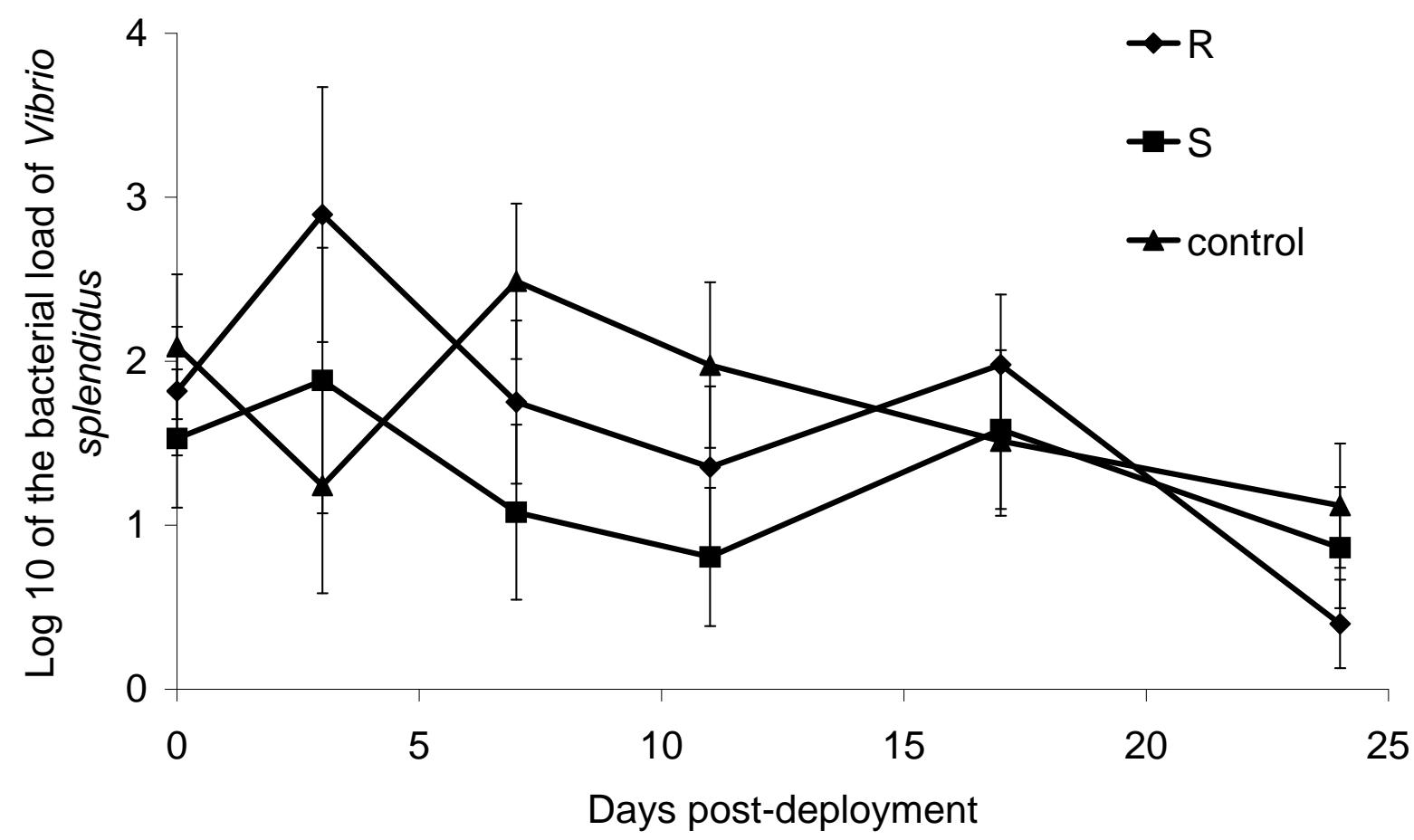

Fig. 3. Kinetics of the prevalence and the bacterial load (number of colonies per $g$ of fresh tissue) of Vibrio splendidus for the $\mathrm{R}, \mathrm{S}$ and control batches (bars represent the standard error). R and S are selected oyster groups, 'resistant' and 'susceptible' to summer mortality, respectively. 
Table 1. Correlations between mortality, prevalence and viral load of OsHV-1 and prevalence and bacterial load of $V$. splendidus (The significance probability of the correlation is indicated in italics):

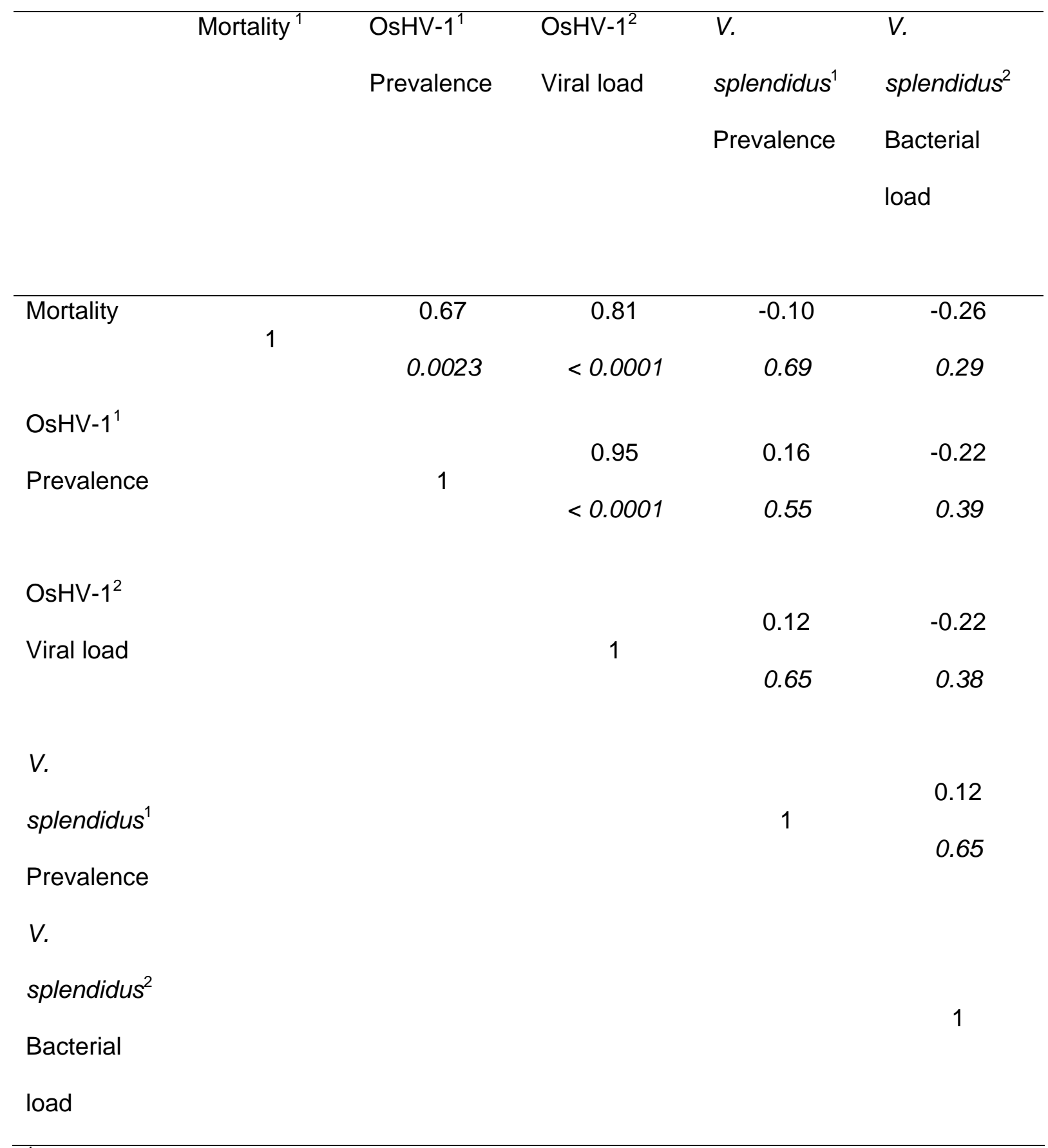

${ }^{1}$ Logistic transformation

${ }^{2}$ Logarithmic transformation 